\title{
Istota relacji sieciowych przedsiębiorstwa
}

https://doi.org/10.33141/po.2005.09.02

Wojciech Czakon
Przegląd Organizacji, Nr 9 (788), 2005, ss. 10-13 www.przegladorganizacji.pl Towarzystwo Naukowe Organizacji i Kierownictwa (TNOiK)

\section{Wprowadzenie}

M anuel Castells ${ }^{1)}$, opisując przedsiębiorstwo sieciowe, jednoznacznie wiąże pojawienie się form organizacyjnych wykraczajacych poza granice formalnoprawne organizacji $\mathrm{z}$ rewolucją informatyczną. Dalej podkreśla jednak, że „formy organizacji gospodarczej nie pojawiają się w próżni społecznej”. Stwarza wrażenie zderzenia dwóch rzeczywistości: nowoczesnej, zwanej wręcz rewolucją technologii informacyjnej, oraz tradycyjnej, osadzonej w kulturowych i instytucjonalnych uwarunkowaniach działalności gospodarczej człowieka. Wydaje się jednak, że wpływ technologii informatycznych jest niejednoznaczny i zmienny. Powoduje to potrzebę zastosowania odmiennych założeń metodologicznych, ale też ontologicznych. Wykraczałoby to poza ramy nie tylko tego artykułu, a być może nawet poza obecne paradygmaty zarządzania.

Wobec rozległości problemu przyczyn i skutków najnowszych zmian w zarządzaniu przedsiębiorstwem zachodzi potrzeba zawężenia rozważań. Na potrzeby tego artykułu autor ograniczy się do zagadnienia istoty sieci przedsiębiorstwa, zwanej także przedsiębiorstwem poszerzonym. Po zwięzłym przedstawieniu badań nad współdziałaniem przedsiębiorstw przedstawione zostaną kolejno: wymiana w ramach relacji, zaangażowanie w relację oraz wzajemność relacji jako cechy specyficzne relacji sieciowych przedsiębiorstwa.

\section{Pluralizm poznawczy badań nad współdziałaniem przedsiębiorstw}

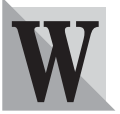

spółdziałanie gospodarcze podmiotów rynku wywołuje coraz większe zainteresowanie nauk ekonomicznych. Istnieje bardzo wiele dowodów empirycznych na to, że gospodarstwa domowe współdziałają z producentami, producenci współdziałają między sobą, nawet państwo współdziała z producentami.

Na gruncie nauk ekonomicznych to zainteresowanie badawcze wydaje się wiązać z wpływem nowej ekonomii instytucjonalnej, a w jej ramach teorii kosztów transakcyjnych. Odrzucają one klasyczne dla modeli mikroekonomicznych założenia homogeniczności rynku, jego atomizacji, a także założenie doskonałej informacji. Wskutek tego wyłania się ograniczony w swojej racjonalności decydent, który przejawia skłonność do zachowań oportunistycznych. Aby ograniczyć ryzyko z tym związane, a także koszty transakcyjne, które stąd wynikają, przedsiębiorstwa tworzą poro- zumienia pomiędzy sobą. Takie podejście urealnia, ale też komplikuje dotychczasowe wyjaśnienia zjawisk ekonomicznych.

Nauka o zarządzaniu stosunkowo wcześnie ujęła problem współdziałania przedsiębiorstw w swoich badaniach. Szczególnie widoczny był lawinowy przyrost badań nad aliansami strategicznymi w latach 80 . ubiegłego wieku. Starano się uzupełnić lukę wiedzy narastającą równie szybko, jak rozpowszechniała się ta forma współdziałania. Obecnie nurt badań nad współdziałaniem przedsiębiorstw uległ rozszerzeniu i pogłębieniu. Wyodrębnić w nim można następujące kierunki oraz obiekty badań:

- konkurencja grup przedsiębiorstw ${ }^{2)}$, czyli pojawienie się rywalizacji rynkowej całych zbiorowości w miejsce konkurencji pojedynczych przedsiębiorstw. Najczęściej występujące nazwy obiektów badawczych to: klastry, konstelacje wartości, sieci czy korporacje wirtualne;

- restrukturyzacja wielkich organizacji ${ }^{3)}$ związana z presją konkurencyjną, wymaganiami akcjonariuszy i potrzeba elastyczności. Charakterystyczne nazwy w tym nurcie problemowym to: organizacja sieciowa, outsourcing, dodatkowa organizacja (collateral organization), modele biznesu, alianse pionowe, łańcuch wartości;

- zjawisko współdziałania wielu przedsiębiorstw $^{4)}$ jako powszechnie występujące w praktyce gospodarczej, a posiadajace pewne cechy szczególne. Najczęściej spotyka się takie nazwy, jak: sieci międzyorganizacyjne, grupy biznesu, kapitalizm aliansów, społeczności, sieci społeczne.

Wymienione kierunki badawcze koncentrują się na rozpoznaniu obiektywnie istniejącego zjawiska z różnych perspektyw. Uporządkowanie tych poczynań jest tym trudniejsze, że w każdym z tych nurtów co innego stanowi podstawowąjednostkę analizy: zbiorowość przedsiębiorstw traktowana jako odrębny byt, albo przedsiębiorstwo rozumiane jako pewna konfiguracja procesów gospodarczych, albo też pojedyncze więzi pomiędzy przedsiębiorstwami.

Ten pluralizm poznawczy wywołuje potrzebę osadzenia dalszych rozważań na określonych założeniach i pojęciach podstawowych. Powinny one umożliwiać z jednej strony nawiązanie do dotychczasowego dorobku nauki, a z drugiej, przyczyniać się do eliminacji narastającego zjawiska woluntaryzmu pojęciowego. Przyjmuje się na potrzeby dalszych rozważań założenie o rozpatrywaniu zjawiska współdziałania z punktu widzenia pojedynczego przedsiębiorstwa. Uwagę badawczą skupia się więc na relacjach pojedynczego 
przedsiębiorstwa z innymi podmiotami. Pozostaje to spójne z zakresem przedmiotowym nauki o zarządzaniu przedsiębiorstwem, podejmując jednocześnie próbę wypełnienia luki niekompletności ${ }^{5}$. Umożliwia również podjęcie próby zdefiniowania sieci przedsiębiorstwa.

„Sieciowość” oznacza tu skupienie uwagi na relacjach występujących pomiędzy przedsiębiorstwem a podmiotami jego otoczenia. Zdaniem L. Krzyżanowskiego wyróżnić należy dwa typy relacji ${ }^{6}$, tj.:

- „stosunki, orzekane jako występujące pomiędzy dwoma lub więcej przedmiotami w sensie epistemologicznym". Można je wyróżniać m.in. ze względu na usytuowanie przestrzenne, następstwo czasowe, wielkość, funkcje, podobieństwo, przynależność, przystawanie, zgodność itp.;

- „oddziaływania, rzeczywiście zachodzące pomiędzy dwoma lub więcej realnymi przedmiotami”. Są więc zjawiskiem konkretnym, określonym pod względem czasu, miejsca oraz przepływu (materialnego, energetycznego, informacyjnego).

Realne istnienie przepływów w sieci przedsiębiorstwa nie budzi wątpliwości. Zatem definiowanie sieci w istocie odnosi się do oddziaływań zwanych alternatywnie więziami. Literatura przedmiotu eksponuje połaczenie wymiaru gospodarczego (oddziaływania istniejące ze względu na działalność przedsiębiorstwa) oraz społecznego (oddziaływania istniejące ze względu na społeczny kontekst przedsiębiorstwa). Wobec tego autor proponuje następującą definicję sieci przedsiębiorstwa:

Sieci przedsiębiorstw stanowią określona przestrzeń współdziałania względnie niezależnych podmiotów, tworzoną ze względu na ich wspólne lub indywidualne cele, w której istnieją więzi gospodarcze i społeczne, a zarzadzanie realizowane jest poprzez umowy oraz interpersonalne procesy decyzyjne.

Ambicją tej definicji jest objęcie szerokiego zakresu różnorodnych zjawisk empirycznych zachodzących nie $\mathrm{w}$ przedsiębiorstwach, ale pomiędzy nimi. Pojęcie przestrzeni spełnia tę ambicję, a przy tym przywodzi na myśl wielowymiarowość.

Tym niemniej istnieć musi określony wyróżnik tych więzi o cechach sieciowych, który czyniłby sieć obiektem względnie homogenicznym oraz wyodrębnionym z otoczenia. Przecież nie wszystkie więzi przedsiębiorstwa można traktować jako sieć.

\section{Cechy więzi sieciowych - wymiana, zaangażowanie i wzajemność}

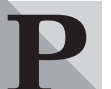

oszukiwanie odrębności sieci od pozostałych więzi przedsiębiorstwa z podmiotami otoczenia prowadzić może albo do skupienia się na cechach tych więzi, albo też na cechach układu tych więzi, tj. całych sieci ${ }^{7}$. Ponieważ to relacje stanowią o istocie sieci wydaje się niezbędne ich prawidłowe zdefiniowanie. Pozwoli to uniknać błędów: poszerzenia, czyli traktowania jako sieciowych wszystkich więzi przedsiębiorstwa, oraz zawężenia, czyli traktowania jako sieci tylko niektórych więzi sieciowych przedsiębiorstwa.

Pluralizm poznawczy skutkuje propozycjami różnych cech i zbiorów cech. Ich analiza semantyczna i porównawcza pozwala zaproponować trzy atrybuty relacji sieciowych: wymianę, zaangażowanie oraz wzajemność.

\section{Wymiana}

Teorie wymiany oraz kosztów transakcyjnych stanowia chronologicznie pierwszy stosowany w badaniach nad więziami sieciowymi fundament poznawczy. Pierwotnie wyodrębniano dwie formy organizacji wymiany: rynek, oparty na cenowym mechanizmie alokacji zasobów, oraz hierarchię, opartą na alokacji administracyjnej.

Badania empiryczne dowiodły jednak istnienia innych typów transakcji, które posiadają swoje własne atrybuty. Szeroko cytowani P.S. Ring i A.H. Van de $\mathrm{Ven}^{8}$, wprowadzili czteroelementową typologię więzi wymiany: rynkową, hierarchiczną, rekurencyjną, relacyjną.

Przytoczona typologia pozwala stwierdzić z całą pewnością, że obok transakcji rynkowych oraz alokacji zasobów w ramach organizacji, zachodzą również inne rodzaje wymiany. Wyróżnia je powtarzalność, charakterystyczna dla hierarchii, oraz odrębność organizacyjno-prawna - charakterystyczna dla rynku. Wyłania się tu niejednoznaczna kategoria wymiany nierynkowej i niehierarchicznej. Przy tym podstawa wyodrębnienia więzi relacyjnych od rekurencyjnych jest poziom postrzeganego ryzyka i zaufania stron. Relacyjne więzi to takie, gdzie poziom postrzeganego ryzyka jest wysoki, a zaufanie pomiędzy stronami silne.

Typologia wymiany skupia sie na przepływach materialnych i energetycznych. W tej refleksji brakuje odniesienia do wymiany informacji. Tymczasem istnieje bogata literatura w zakresie informacyjnego wymiaru przepływów sieciowych. Stwierdza się m.in., że przedsiębiorstwa mają różny dostęp do informacji ze względu na posiadaną sieć społeczną. Przy tym koszt dostepu do informacji nie jest czynnikiem istotnym ${ }^{9}$. Badania empiryczne pokazują, że sieciowa struktura więzi informacyjnych ma podstawowe znaczenie w działalności przedsiębiorstwa. Przykładem takiego stanu rzeczy może być bankowość inwestycyjna, realizowana w warunkach odrębności organizacyjno-prawnej uczestników, którzy jednak powiązani są gęstą siecią społecznych przepływów informacyjnych. Decydują one o powodzeniu przedsiębiorstwa na rynku ${ }^{10)}$

Zatem więzi sieciowe to pewna struktura relacji przedsiębiorstwa, poprzez które zachodzi wymiana informacyjna, materialna i energetyczna. Co do treści, relacje sieciowe nie różnią się od innych więzi przedsiębiorstwa. Stanowić zatem będą pewną klasę więzi przedsiębiorstwa ze względu na inne cechy (kryteria).

\section{Zaangażowanie}

Poszukiwanie specyfiki wymiany relacyjnej prowadzi do kategorii zaangażowania, rozumianego jako pogłębianie i poszerzanie istniejących relacji wymiany ${ }^{11}$. Jeżeli relacje sieciowe wyróżniają się pod względem zaangażowania, to powstaje pytanie: jakie są przejawy tego zaangażowania? 
Badania porównawcze nad przemysłem motoryzacyjnym amerykańskim i japońskim pozwoliły stwierdzić istnienie wyższej efektywności ze względu na relacyjne zaangażowanie występujące w koncernach japońskich ${ }^{12)}$.

Przy wykorzystaniu takich pojęć teorii kosztów transakcyjnych jak: oportunizm, zasób specyficzny, koszt transakcyjny, odkryto niespójność teorii z empirią. Otóż wbrew predykcjom teoretycznym koszty transakcyjne maleją wraz ze wzrostem specyficzności aktywów.

Specyficzność zasobów oznacza w tym przypadku takie zasoby, których nie można, lub można jedynie w ograniczonym stopniu, używać do relacji z innymi klientami. Miary operacyjne specyficzności obejmować mogą: odległość zakładów produkcyjnych współdziałających przedsiębiorstw (specyficzność lokalizacji); udział aktywów produkcyjnych specyficznych dla danej relacji w aktywach produkcyjnych ogółem (specyficzność techniczna); liczbę roboczogodzin bezpośredniego kontaktu przedstawicieli handlowych z pracownikami klienta (specyficzność zasobów ludzkich).

Cytowane badania J. Dyera doprowadziły do sformułowania pięciu czynników wpływających na niższe koszty transakcyjne w relacyjnym zarządzaniu modelu japońskiego, przedstawionych na rysunku.

Wielowymiarowe zaangażowanie odróżnia więc zwykłe transakcje przedsiębiorstwa od współdziałania w ramach więzi relacyjnych. Podkreślić trzeba, że zaangażowanie jest cechą mierzalną, stopniowalną i względną.

Zaangażowanie w relacje staje się mechanizmem zabezpieczającym przed oportunizmem ${ }^{13)}$. S. Jap i E. Anderson stwierdziły empirycznie, że zaangażowanie inwestycyjne jest silnym mechanizmem zabezpieczającym niezależnie od poziomu oportunizmu. Zaangażowanie społeczne jest efektywnym zabezpieczeniem
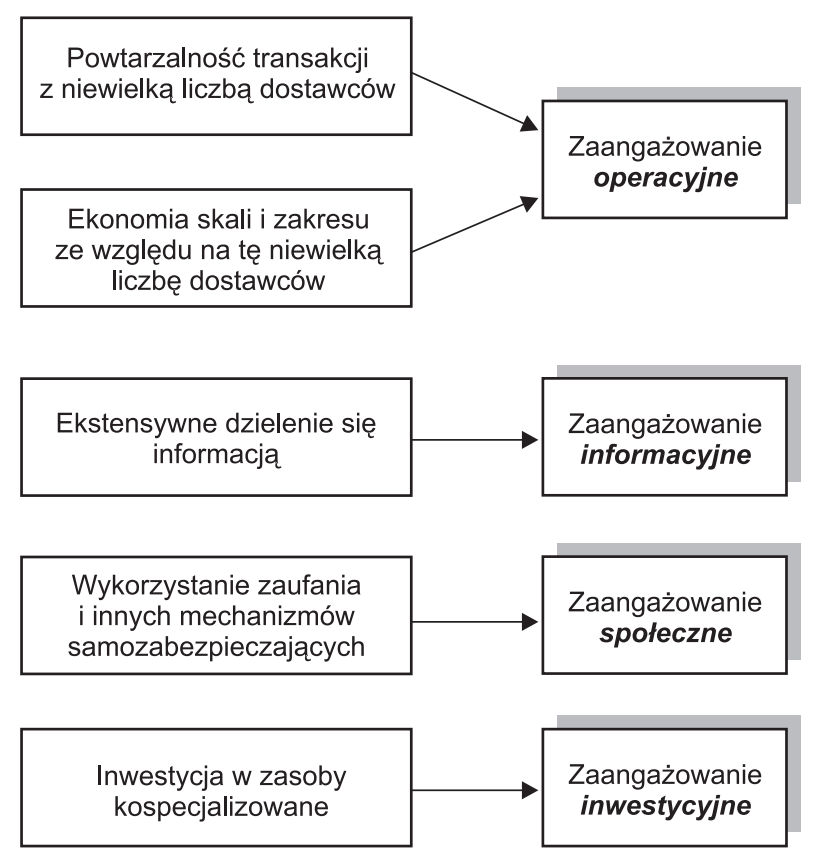

Rys. Rodzaje zaangażowania w relację Źródło: opracowanie własne na podstawie: J. DYER, Effective Interfirm Cooperation..., s. 543-544. w warunkach niskiego poziomu oportunizmu. Natomiast zaangażowanie informacyjne zabezpiecza tym efektywniej, im poziom oportunizmu jest wyższy.

Zaangażowanie jako cecha szczególna więzi sieciowych pojawia się również w próbach zdefiniowania sieciowego porządku władzy ${ }^{14)}$. Stwierdza się istnienie dwóch grup czynników wyróżniających sieciowy porządek władzy: związanych z wymianą oraz związanych z osadzeniem społecznym. Czynniki związane $\mathrm{z}$ wymianą to m.in.: unikatowe wyposażenie techniczne, procesy gospodarcze, wiedza ludzi. Osadzenie społeczne obejmuje zaufanie, reputację, dyfuzję informacji oraz sankcje zbiorowe przeciw ewentualnym oportunistom.

Nie ulega zatem wątpliwości, że zaangażowanie to atrybut relacji sieciowej. Jeżeli jednak byłoby ono jednostronne, to relacja taka nie spełniałaby warunków sieciowości.

\section{Wzajemność}

Zgodnie z zaproponowaną definicją sieci przedsiębiorstwa, zjawisko to zachodzi pomiędzy względnie niezależnymi podmiotami. Na gruncie nauk prawnych stwierdzić trzeba, że strony zawierają pomiędzy sobą umowy. Przewidują one wzajemność świadczeń jako fundament wszelkich umów cywilnych. Odnosząc się do istoty więzi relacyjnych stwierdza się też, że wyrażają się one w postaci tzw. umów relacyjnych. Oznacza to wysoki poziom współpracy, wspólnego planowania, obopólnej adaptacji do potrzeb partnera ${ }^{15)}$. Definiując wzajemność wykracza się więc poza działania jednostronne, symetryczne do zachowań partnera. Obok wzajemności (reciprocity) pojawia się wspólnota (mutuality).

W literaturze wyróżnić można dwa sposoby rozumienia wzajemności, oparte alternatywnie na władzy lub na wspólnocie.

Podejście oparte na władzy ${ }^{16)}$ przejawia trzy wymiary: stopnia obopólności (mutuality), symetryczności oraz struktur władzy. Wzajemność jest tu cechą stopniowalną, pojawiającą się jako skutek dwustronnych dążeń do dominacji partnera. Takie rozumienie pojawia się u tych autorów, którzy w nawiązywaniu więzi relacyjnych dostrzegają próbę ograniczenia zasobowych słabości przedsiębiorstwa. Usiłuje ono przejąc kontrolę nad zasobami partnerów.

Podejście oparte na wspólnocie ${ }^{17)}$ odnosi się do równowagi, dwustronności, równości stron. W tym ujęciu nawiązywanie relacji sieciowych stanowi wyraz wspólnych celów lub możliwości pełniejszego osiągania celów we współdziałaniu z innymi przedsiębiorstwami. Zakłada się, że niedoskonałość zasobowa przedsiębiorstwa oraz proces tworzenia więzi jest dobrowolny i obopólny. Nie odbywa się pod przymusem, w warunkach dominacji. Strony antycypują przyszłe korzyści ze współpracy, a to skłania je do harmonijnego odwzajemniania wysiłków.

Wzajemność oddziaływań znacznie wykracza poza transakcje kupna-sprzedaży. Obejmuje wymianę informacji oraz wspólne, skoordynowane podejmowanie decyzji na tej podstawie ${ }^{18)}$. Więzi sieciowe mogą spełniać rolę koordynacyjną, którą się im przypisuje, właśnie ze względu na wzajemność więzi. W terminologii 
analizy sieciowej oznacza to, że więzi są ukierunkowane i dwustronnie skierowane ${ }^{19)}$.

Wzajemność jest kluczowym elementem oceny więzi przez jej strony ${ }^{20}$. Ocena stanowi mechanizm budowania, weryfikacji, modyfikacji lub przyczynę rozwiązania relacji. Obejmuje ona według P.S. Ring i A.H. Van de Vena: zaangażowanie stron, proces negocjowania umowy oraz wykonanie umowy przez strony. Oznacza to, że ocena obejmuje wymianę zachodząca pomiędzy stronami - od etapu tworzenia umowy pomiędzy stronami do kontroli zgodności jej wykonania z przyjętymi założeniami. Ocena zachodzi również $\mathrm{w}$ trakcie istnienia relacji i dotyczy stopnia oraz wzajemności zaangażowania wykazywanego przez partnerów. Wobec tego cechami więzi sieciowych są łącznie wymiana, zaangażowanie oraz wzajemność. Każda $\mathrm{z}$ nich stanowi przedmiot oceny, dalej uruchamiajac procesy uczenia się i adaptacji lub też zakończenia współdziałania stron.

Badania empiryczne dowodzą także, że poczucie wzajemności przy podziale korzyści gospodarczych jest warunkiem trwania współpracy ${ }^{21)}$. Rozpatrywano dwa sposoby podziału: według wkładu lub „po równo”. Drugi sposób chętniej stosuje się w warunkach troski o trwałość relacji, jakość tej relacji, a także wówczas, gdy zachodzi trudność dokładnej wyceny wkładu stron. Wykazano, że stosowanie podziału według wkładu nie sprzyja trwałości więzi.

\section{Podsumowanie}

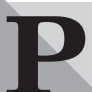

roponowane cechy więzi sieciowej mają charakter konstytutywny, tj. stanowią o tym, czy dana więź jest czy nie jest sieciowa. Zaproponować można następującą definicję: więzi sieciowe to takie oddziaływania zachodzace pomiędzy przedsiębiorstwami, w których zachodzi wymiana informacyjna, materialna lub energetyczna, przy czym strony wymiany przejawiają zaangażowanie, a postawa ta jest wzajemna.

Wydaje się, że ta propozycja spełnia walory zwięzłości oraz zgodności z intuicyjnym rozumieniem istoty relacji sieciowych.

Przypomnieć jednak trzeba w tym miejscu społeczno-gospodarczy charakter przestrzeni współdziałania przedsiębiorstw. Więzi sieciowe zachodzić mogą bowiem pomiędzy ludźmi, pomiędzy ludźmi a organizacjami oraz pomiędzy organizacjami ${ }^{22}$. Wynika stąd, że przedsiębiorstwo jest „zanurzone” w wielopoziomowej, dynamicznej strukturze więzi. Powstaje zatem problem, jak można taką strukturą zarządzać?

Odrębną kwestią jest dynamika więzi przedsiębiorstwa. Niektóre spośród nich jeszcze nie są sieciowe, inne już nie sa, choć były, a jeszcze inne nigdy nie będą. Wywołuje to potrzebę prowadzenia dalszych badań, poświęconych wyłącznie problemowi dynamiki sieci przedsiębiorstwa.

dr Wojciech Czakon Akademia Ekonomiczna w Katowicach Katedra Zarządzania Przedsiębiorstwem

\section{PRZYPISY}

1) M. CASTELLS, The Rise of the Network Society, II wydanie, Blackwell Publishing, Oxford 2000, s. 184-187.
2) B. GOMES-CASSARES, Group Versus Group: How Alliance Networks Compete, „Harvard Business Review” 1994, vol. 92, nr 4, s. 62-74.

3) R.S. ACHROL, Changes in the Theory of Interorganizational Relations in Marketing: Toward a Network Paradigm, „Academy of Marketing Science Journal” 1997, vol. 25 , nr 1, s. 56-71.

4) C. JONES, W.S. HESTERLY, S.P. BORGATTI, A General Theory of Network Governance: Exchange Conditions and Social Mechanisms, „Academy of Management Review" 1997, vol. 22, $\mathrm{nr}$ 4, s. 911-945.

5) Szerzej na ten temat autor wypowiada sie [w:] W. CZAKON, Ku systemowej teorii przewagi konkurencyjnej przedsiębiorstwa, „Przegląd Organizacji” 2005, nr 5, s. $5-9$.

6) L. KRZYŻANOWSKI, $O$ podstawach kierowania organizacjami inaczej, PWN, Warszawa 1999, s. 165.

7) Szerzej w tym względzie wypowiada się np.: J. NIEMCZYK, Sieć jako obiekt badań w naukach o zarzadzaniu, [w:] Management Forum 2020, K. KRZAKIEWICZ, S. CYFERT (red.), AE, Poznań 2003, s. 116-125.

8) P.S. RING, A.H. VAN de VEN, Structuring Cooperative Relationships Between Organizations, „Strategic Management Journal" 1992, vol 13, nr 7, s. 483-498.

9) S.P. BORGATTI, R. CROSS, A Relational View of Information Seeking and Learning in Social Networks, „Management Science" 2003, vol. 49, nr 4, s. 432-445.

10) R.G. ECCLES, D.B. CRANE, Managing Through Networks, „California Management Review” 1987, vol. 30, nr 1, s. 176-195.

11) J.C. ANDERSON, H. HAKANSSON, J. JOHANSON, Dyadic Business Relationships Within a Business Network Concept, „Journal of Marketing” 1994, vol. 58, nr 4, s. $1-15$.

12) J. DYER, Effective Interfirm Cooperation: How Firms Minimize Transaction Costs and Maximize Transaction Value, „Strategic Management Journal” 1997, vol. 18, nr 7, s. 535-556.

13) S. JAP, E. ANDERSON, Safeguarding Interorganizational Performance and Continuity Under Ex Post Opportunism, „Management Science” 2003, vol. 49, nr 12, s. $1684-1701$.

14) C. JONES, W.S. HESTERLY, S.P. BORGATTI, A General Theory of Network..., op.cit.

15) C.J. LAMBE, R.E. SPEKMAN, S.D. HUNT, Intermistic Relational Exchange: Conceptualization and Propositional Development, „Academy of Marketing Science Journal" 2000, vol. 28, nr 2, s. 212-225.

16) M. HOLMLUND, What are Relationships in Business Networks, „Management Decision” 1997, vol. 35, nr 4, s. 304-311.

17) C. OLIVIER, Determinants of Interorganizational Relationships: Integration and Future Directions, „Academy of Management" 1990, vol. 15, nr 2, s. 241-265.

18) D. H. BLANKENBURG, K. ERIKSSON, J. JOHANSON, Business Networks and Cooperation in International Business Relationships, „Journal of International Business Studies" 1996, vol. 27, nr 5, s. 1033-1053.

19) S. WASSERMAN, K. FAUST, Social Network Analysis, Cambridge University Press 1994, s. 121-123.

20) P.S. RING, A.H. VAN de VEN, Developmental Process of Cooperative Interorganizational Relationships, „Academy of Management Review” 1994, vol. 19, nr 1, s. 90-118.

21) S. JAP, „Pie Sharing” in Complex Collaboration Context, „Journal of Marketing Research” 2001, vol. 38, nr 1, s. 86-99.

22) A.L. OLIVER, J.P. LIEBESKIND, Three Levels of Networking for Sourcing Intellectual Capital in Biotechnolo$g y$, „International Studies of Management and Organization" 1997, vol. 27, nr 4, s. 76-103. 